\title{
Preliminary Maps of Crustal Thickness and Regional Seismic Phases for the Middle East and North Africa
}

Jerry J. Sweeney

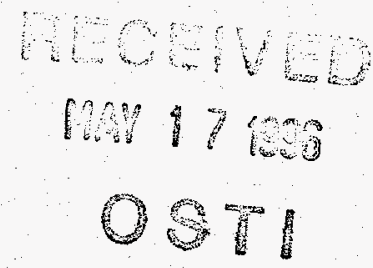

September 6, 1995

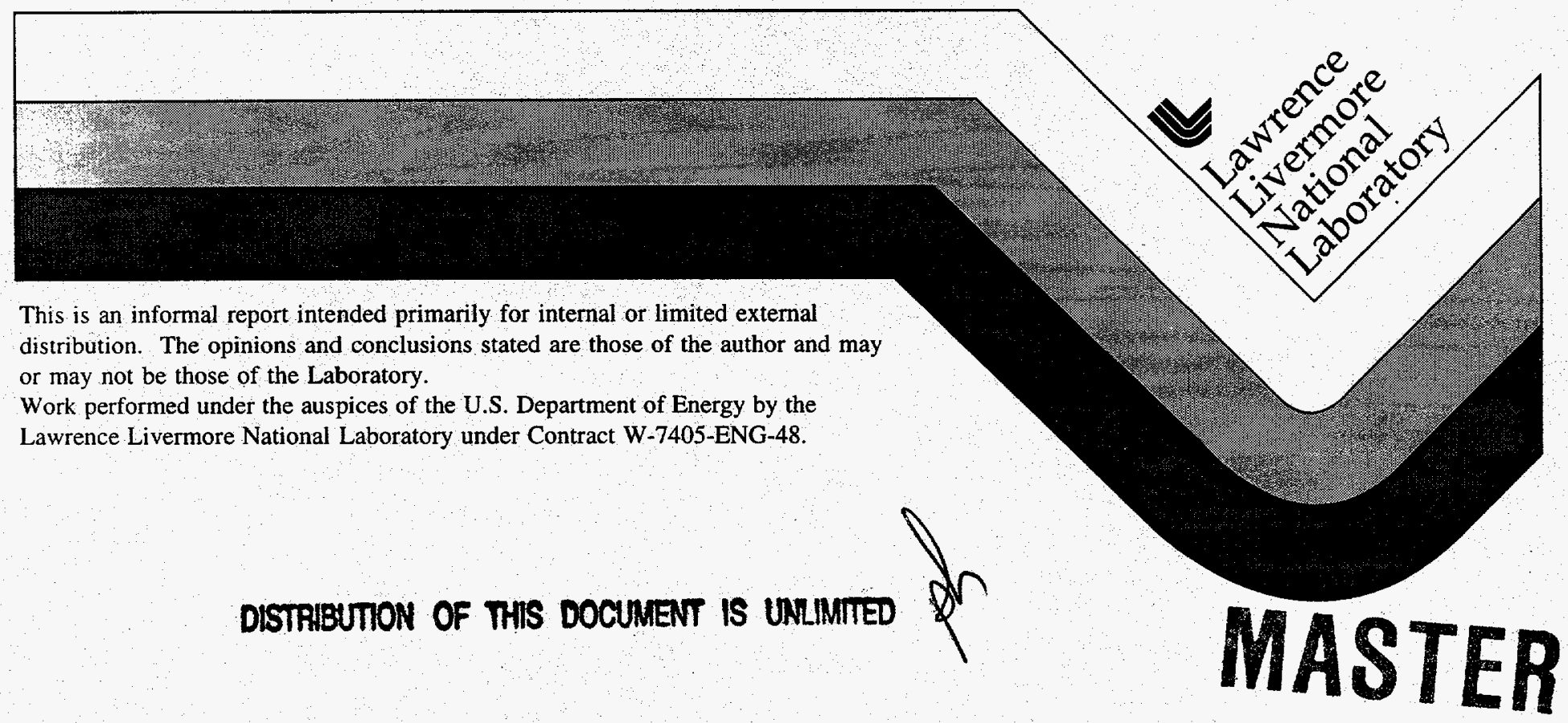




\section{DISCLAIMER}

This document was prepared as an account of work sponsored by an agency of the United States Government. Neither the United States Government nor the University of California nor any of their employees, makes any warranty, express or implied, or assumes any legal liability or responsibility for the accuracy, completeness, or usefulness of any information, apparatus, product, or process disclosed, or represents that its use would not infringe privately owned rights. Reference herein to any specific commercial product, process, or service by trade name, trademark, manufacturer, or otherwise, does not necessarily constitute or imply its endorsement, recommendation, or favoring by the United States Government or the University of California. The views and opinions of authors expressed herein do not necessarily state or reflect those of the United States Government or the University of California, and shall not be used for advertising or product endorsement purposes.

This report has been reproduced directly from the best available copy.

Available to DOE and DOE contractors from the Office of Scientific and Technical Information P.O. Box 62, Oak Ridge, TN 37831

Prices available from (615) 576-8401, FTS 626-8401

Available to the public from the National Technical Information Service

U.S. Department of Commerce 5285 Port Royal Rd. Springfield, VA 22161 


\section{DISCLAMTER}

Portions of this document may be illegible in electronic image product Images are produced from the best available original document. 


\title{
Preliminary Maps of Crustal Thickness and Regional Seismic Phases for the Middle East and North Africa
}

\author{
Jerry J. Sweeney \\ Lawrence Livermore National Laboratory \\ Regional Seismic Analysis Project
}

\section{Introduction}

As part of the development of regional seismic discrimination methods for the Middle East and North Africa (MENA) we are building a database of information related to seismic propagation and crustal structure as well as associated geologic-tectonic and geophysical data. We hope to use these data to construct and test models of regional seismic propagation and evaluate various detection/discrimination scenarios. To date, the database has been developed by building on a list of references for MENA provided by the Institute for the Study of the Continents (INSTOC) at Cornell University (Fielding et al., 1994). To this list we have added an equal number of references resulting from our own literature search which has emphasized papers dealing with seismicity and regional and teleseismic phase data. This paper represents an initial attempt to consolidate some of the information from the database into a form useful to researchers modeling regional seismic waveforms. The information compiled in this report is supplemental to the INSTOC database and, to my knowledge, has not been compiled anywhere else.

What follows is a series of maps which illustrate the spatial variation of seismic phase velocities and crustal thickness. The text below identifies the sources of information used in the map preparation. Data for the compilation of these maps has come from an initial search of the database as it presently exits and is not intended to be exhaustive. We hope that this initial exercise will help to identify areas and types of data that are deficient and help to focus future data gathering activities.

\section{Explanation of map titled "Generalized Tectonic Map of the Middle East and North Africa" (Fig. 1)}

This map is included as a reference map for tectonic structures of the region. The primary sources used to construct this map are Adams and Barazangi (1984), Berberian (1981), Mindevalli and Mitchell (1989), Nowroozi (1972), and Nowroozi (1987). The map shows only large-scale tectonic features such as zones of continental collision, subduction of oceanic crust, large scale transform faults, and areas of ocean spreading or incipient rifting.

The Arabian Plate and the African Plate are moving away from each other, producing the Red Sea rift zone. New oceanic crust is being formed in a narrow zone along the rift axis. Each side of the rift consists of a wide zone of subsided blocks of continental crust with a fairly sharp transition to oceanic crust near the present-day shoreline of the Red Sea. The Arabian Plate is moving NE relative to the African Plate, Iran, and the Mediterranean. The northwest boundary of the Arabian Plate is the left-lateral Dead Sea Fault Zone. The southeast boundary of the Arabian Plate is the Owen Fracture Zone (OFZ) in the northwestern Indian ocean. I follow Berberian (1981) and others in showing the OFZ with right lateral movement. Nowroozi (1972) and Nowroozi (1987) show the OFZ with left lateral movement. Along the northeastern boundary of the Arabian Plate, Paleozoic sediments of the Arabian Platform are being pushed under Iran along the Zagros Mountains. The main expression of this continent-continent collision zone is a wide zone of folding and shallow earthquakes terminated abruptly to the northeast along a regional-scale thrust fault referred to as the Main Zagros Thrust Zone (MZT on the map). A very large portion of the huge oil reserves of the Middle East are found in reservoirs located updip among the Paleozoic sediments of the Arabian Platform as it tilts to the northeast, especially 
in and around the Persian Gulf. The shallow thrusting in the Zagros region may be facilitated by slip within the upper Precambrian Hormoz evaporite (Berberian, 1981). Other zones of major thrusting associated with the convergence of the Arabian Platform and Asia are those marked as thrust faults along the southern shore of the Caspian Sea and along the line separating the northern and southern Caspian Sea extending northwest to the north shore of the Black Sea.

Turkey is being squeezed out to the west by the collision of Arabia and Asia. The main motion of the Turkish Platform is taken up by the right-lateral North Anatolian Fault zone and the left-lateral East Anatolian Fault zone. Extreme western Turkey is undergoing tension, with a combination of strike-slip and normal faulting mechanisms dominating the seismicity. Oceanic subduction is occurring along at least part of the southern part of the Aegean and Sicily. The East Anatolian Fault may extend to the southwest along the southern coast of Cyprus. On the map I have shown a relatively small area of rifting in the Sirt Basin of Libya, where most of the Libyan oil reserves are found. This rift zone has been active for an extensive geologic period and shows moderate seismicity at the present day. In northwest Africa, continent-continent convergence of Africa and Europe are expressed by a series of thrust zones and folded Paleozoic-Mesozoic sediments in the Atlas ranges extending from northern Tunisia through northern Algeria and Morocco.

\section{Explanation of map titled "Pn velocities in the Eastern Mediterranean" (Fig. 2)}

The map covers the area of the eastern Mediterranean inclusive of Egypt, Saudi Arabia, Iran, Turkey, and the Levant (Israel, Jordan, Lebanon). For coverage of the northern part of the area I relied mainly on the work of Rogers et al. (1995) and Hearn and $\mathrm{Ni}$ (1994). Rogers et al. used an analysis of travel time, amplitude, and frequency of regional wave forms to construct a contoured map of regional Pn velocities (their Fig. 2). This map is quite similar to Fig. 3a presented by Hearn and $\mathrm{Ni}$, which was constructed using tomographic imaging. Other Pn data from Turkey and Iran come from Asudeh (1982), Chen et al. (1980), Kadinsky-Cade et al. (1981), and Ezen (1991). Asudeh used a two-station method, which was purported to be independent of station location errors, to determine Pn velocities along several paths. He found unusually high Pn velocity (8.3 $\mathrm{km} / \mathrm{s}$ ) beneath the Zagros region of Iran (refer to Fig. 1). Chen et al. used the travel timedistance relation method for well-located earthquakes with seismograms recorded at Istanbul, Tabriz, Meshed, and Shiraz. The Kadinsky-Cade et al. study used short period WWSSN wave forms. The study by Ezen looked at dispersion of surface waves using crustal structure models in the Burdur region of western Turkey. A study by Panagiotopoulos and Papazachos (1985) used earthquake locations determined by portable networks to study travel times in the Aegean and Balkan and western Turkey regions. All of these studies were generally consistent. In places where results disagreed by more than $0.2 \mathrm{~km} / \mathrm{s}$, I used the results of Rogers et al. (1995) because they were the most recent and based on regional data.

Coverage of parts of the area not covered as thoroughly by Rogers et al. was enhanced by studies related to the USGS 1978 long range seismic refraction line in Saudi Arabia (Badri, 1991; Mechie et al., 1986; and maps in Fielding et al., 1994) and by a study (Hofstetter et al., 1991) of P-wave travel time residuals from teleseisms recorded by the Israel seismic network. The study by Mechie et al. noted a $20 \mathrm{~km}$ jump in Moho depth in the transition from the Red Sea (thin crust) to the Arabian shield (thicker crust).

\section{Explanation of map titled "Depth to Moho/Crustal Thickness (km)" (Fig. 3)}

A summary by Soller et al. (1982), which includes a world-wide crustal thickness map, provides a starting point for this region. These data were supplemented by an 
additional compilation of data from over 100 sources by Geiss (1987). The data of Geiss concerns mainly the northern part of the Mediterranean, with poor resolution for the southern (Africa) side. A detailed crustal thickness map of Egypt is included in Fielding et al. (1994). A study of seismic reflection data in Syria by Al Saad et al. (1992) included estimates of crustal thickness based on gravity modeling. We used estimates of crustal thickness in Turkey provided by Mindevalli and Mitchell (1989) based on study of intermediate period Rayleigh and Love wave phases. For the area of the eastern Mediterranean (Israel and Jordan) we used results of an analysis of seismic refraction data by Ginzberg et al. (1979) which covered the Jordan-Dead Sea-Gulf of Elat and included the transition between the Mediterranean and the Arabian shield. The $50 \mathrm{~km}$ contour line in Iran that encompasses the region of the main Zagros thrust zone is based on interpretation and modeling of gravity data by Snyder and Barazangi (1986). Interpretation of long period shear phases by Hadiouche and Zurn (1992) provides very crude constraints on crustal thickness in northeastern Africa and the Arabian peninsula; more detailed crustal thickness data for Saudi Arabia comes from interpretations of the 1978 USGS refraction line (Mechie et al., 1986 and Fielding et al., 1994).

\section{Explanation of maps titled "Lg Q values" (Fig. 4), "Lg and Sn velocities" (Fig. 5), and "Sn propagation (Fig. 6)}

Lg Q values for Iran and eastern Turkey (Fig. 4) are based primarily on the work of Jih and Lynnes (1993) and Kadinsky-Cade et al. (1981). Jih and Lynnes expanded upon earlier work of Nuttli (1980), using a 7-zone regional inversion of $1 \mathrm{~Hz} \mathrm{Lg}$ waves to determine $Q$ and its spatial variation. They also noted that "...inefficient Sn propagation beneath the northern Iranian Plateau...seems to permit efficient Lg propagation..." Kadinsky-Cade et al. also observed the $\mathrm{Sn}$ anomaly and were the first to observe that $\mathrm{Lg}$ phases do not cross the Black Sea or the Caspian Sea. The Kadinsky-Cade et al. values of Lg and Sn velocity (Fig. 5) are the only such data we have found for this region. The unusual range of $\mathrm{Lg}$ velocity $(3.1-3.6 \mathrm{~km} / \mathrm{s})$ shown in Fig. 5 could be an indication of the complexity of the seismograms or structure in the region of the Iranian plateau. Hearn and $\mathrm{Ni}(1994)$ noted that the region of high Sn attenuation (see Fig. 6) was associated with very low Pn velocities. Rogers et al. (1995) noted that Sn propagates efficiently for paths across the Caspian Sea, but was not seen in the areas along the Turkish-Iran border (see Fig. 6). They also associated high $\mathrm{Sn}$ attenuation with low Pn velocities.

Nishigami et al. (1990) used a local array in northwestern Turkey and microearthquake data to determine coda $Q$ over a small $(100 \mathrm{~km}$ by $100 \mathrm{~km})$ region. They found coda $\mathrm{Q}$ (at $5 \mathrm{~Hz}$ and $10 \mathrm{~Hz}$ ) to be about twice as large in the northern part of the region studied, adjacent to the southern shore of the Black Sea (see Fig. 4). In another coda Q study from a local network, van Eck (1988) obtained a value of 65 for the Dead Sea transform region using short period $(1 \mathrm{~Hz})$ data from microearthquakes with hypocentral distances ranging from $10-55 \mathrm{~km}$ (Fig. 4). The area between southwestern Turkey and the island of Crete was studied using 5 ocean bottom seismometers by Kovachev et al. (1991). They estimated Qs at 5-15 Hz to be between 200-300 in this area (Fig. 4).

For the Arabian Peninsula, data in Fig. 4 come from Seber and Mitchell (1992). They looked at $Q$ for Love and Rayleigh waves in the eastern and western parts of the peninsula at periods of 1-30 s. These values of $Q$ ranged between $60-150$, with highest values in the central peninsula and lower values closer (but still far inland) to the Red Sea and in the region of the Zagros fold and thrust zone. Seber and Mitchell also calculated an $\mathrm{Lg} \mathrm{Q}$ for the central region by creating synthetic Lg signals based on velocity-depth models. This value of $\mathrm{Lg} \mathrm{Q}$ for the central Arabian platform came out to be 237, which agrees well with an unpublished measured Lg value that they discuss in the paper. The lower $Q$ values to the northeast agree well with the lower $Q$ values in Zagros determined by Jih and Lynnes. 
Other studies have been done of surface wave dispersion in the MENA region; although these studies were based on long period teleseismic data with low resolution and often not very quantitative, I mention them here because they do provide some insight into phase propagation characteristics in the area. Hadiouche (1990) noted teleseismic (Love waves at 25-130 s period) Q values of 200-300 under the Red Sea. Xie and Mitchell (1990) used back-projection tomography over a relatively coarse grid (covering all of Africa) to estimate surface wave $Q$ using short period $(1 \mathrm{~Hz})$ data. They found the lowest $Q$ to be in the East African Rift, with the area of the Atlas mountains in northwestern Africa (Morocco, northern Algeria, and Tunisia) being also relatively low. Der et al. (1985) found evidence of relatively high upper mantle attenuation under the former French nuclear test site in Algeria, with high attenuation of frequencies greater than $5 \mathrm{~Hz}$ and spectral characteristics similar to the NTS.

\section{Explanation of map titled "Morocco and offshore Atlantic Ocean Pn and Sn velocities" (Fig. 7)}

Pn and $\mathrm{Sn}$ velocities shown in this map come from a study by Marillier and Mueller (1982). They used stations in Spain, Morocco, the Azores and Canaries to determine velocities of $50 \mathrm{~s}$ period teleseismic waves. They observed a large contrast in Sn from north to south across the Azores-Gibraltar Ridge (which they think has been the site of a major plate shear boundary for at least the past $180 \mathrm{~m} . y$.). Seber et al. (1993), used the Moroccan network to look at shear wave arrivals from earthquakes to the northwest, along the Azores-Gibraltar Ridge and near the coast of Spain. Seber et al. refer to a fast $S$ phase, which they determined to be Sn converted to Sg by crustal thickness discontinuities along the continental slope of Morocco. They estimate crustal thickness under Morocco to be about $40 \mathrm{~km}$.

\section{Combined References}

Adams, R. D., and M. Barazangi, 1984, Seismotectonics and seismology in the Arab region; a brief summary and future plans: BSSA, v. 74, p. 1011-1030.

Al-Saad, D., T. Sawaf, A. Gebran, M. Barazangi, J. Best, and T. A. Chaimov, 1992, Crustal structure of central Syria: the intracontinental Palmyride mountain belt: Tectonophysics, v. 207, p. 345-358.

Asudeh, I., 1982, Pn velocities beneath Iran: Earth and Planetary Science Letters, v. 61, p. 136-142.

Badri, M., 1991, Crustal structure of central Saudi Arabia determined from seismic refraction profiling: Tectonophysics, v. 185, p. 357-374.

Berberian, M., 1981, Active faulting and tectonics of Iran: in, H. K. Gupta and F.M. Delany, eds., Zagros Hindu Kush Himalaya Geodynamic Evolution, Geodynamics Series Vol. 3, American Geophysical Union, Washington D.C., p. 33-69.

Chen, C. Y., W. P. Chen, and P. Molnar, 1980, The uppermost mantle P wave velocities beneath Turkey and Iran: Geophysical Research Letters, v. 7, p. 77-80.

Der, Z., T. McElfresh, R. Wagner, and J. Burnetti, 1985, Spectral characteristics of $\mathbf{P}$ waves from nuclear explosions and yield estimation: BSSA, v. 75, p. 379-390. 
Ezen, U., 1991, Surface wave dispersion and upper crustal structure along N-S direction in western Turkey from Burdur earthquake of 12 May 1971: Bulletin of the International Institute of Seismology and Earthquake Engineering, v. 25, p. 39-59.

Fielding, E., M. Barazangi, and B. Isacks, 1994, A Geological and Geophysical Information System for Eurasia, the Middle East, and North Africa - Digital Database Development for the Middle East North Africa, Ithaca, NY, Cornell University.

Geiss, E., 1987, A new compilation of crustal thickness data for the Mediterranean: Annales Geophysicae, v. 5B, p. 623-630.

Ginzburg, A., J. Makris, K. Fuchs, C. Prodehl, W. Kaminski, and U. Amitai, 1979, A seismic study of the crust and upper mantle of the Jordan-Dead Sea rift and their transition toward the Mediterranean Sea: Journal of Geophysical Research, v. 84, p. 1569-1582.

Hadiouche, O., 1990, First evidence for high anelastic attenuation beneath the Red Sea from Love wave analysis: Geophys. Res. Letters, v. 17, p. 1973-1976.

Hadiouche, O., and W. Zurn, 1992, On the structure of the crust and upper mantle beneath the Afro-Arabian region from surface wave dispersion: Tectonophysics, v. 209, p. 179196.

Hearn, T. M., and J. F. Ni, 1994, Pn velocities beneath continental collision zones: the Turkish-Iranian Plateau: Geophys. J. Int., v. 117, p. 273-283.

Hofstetter, A., L. Feldman, and Y. Rotstein, 1991, Crustal structure of Israel: constraints from teleseismic and gravity data: Geophysical J. International, v. 104, p. 371-379.

Jih, R. S., and C. S. Lynnes, 1993, Regional Lg Q variation in Iranian plateau and its implication for $\mathrm{mb}(\mathrm{Lg})$ determination, Phillips Lab report PL-TR-93-2003 (TGAL-93-01), p. 13-37.

Kadinsky-Cade, K., M. Barazangi, J. Oliver, and B. Isacks, 1981, Lateral variations of high-frequency seismic wave propagation at regional distances across the Turkish and Iranian plateaus: JGR, v. 86, p. 9377-9376.

Kovachev, S. A., I. P. Kuzin, O. Y. Shoda, and S. L. Soloviev, 1991, Attenuation of Swaves in the lithosphere of the Sea of Crete according to OBS observations: Physics of the Earth and Planetary Interiors, v. 69, p. 101-111.

Marillier, F., and S. Mueller, 1982, Structure of the upper mantle in the Northeastern Atlantic close to the Azores-Gibraltar ridge from surface-wave and body-wave observations: Tectonophysics, v. 90, p. 195-213.

Mechie, J., C. Prodehl, and G. Koptschalitsch, 1986, Ray path interpretation of the crustal structure beneath Saudi Arabia: Tectonophysics, v. 131, p. 333-352.

Mindevalli, O. Y., and B. J. Mitchell, 1989, Crustal structure and possible anisotropy in Turkey from seismic wave dispersion: Geophysical J. International, v. 98, p. 93-106.

Nishigami, K., Y. Iio, C. Gurbuz, A. Pinar, N. Aybey, S. B. Ucer, Y. Honkura, and A. M. Isikara, 1990, Microseismic activity and spatial distribution of coda- $Q$ in the westernmost part of the North Anatolian Fault Zone, Turkey: Bull. Disas. Prev. Inst., Kyoto Univ., v. 40, p. 41-56. 
Nowroozi, A. A., 1972, Focal mechanism of earthquakes in Persia, Turkey, West Pakistan, and Afghanistan and plate tectonics of the Middle East: BSSA, v. 62, p. 823850.

Nowroozi, A. A., 1987, Tectonics and earthquake risk of Iran: Developments in Geotechnical Engineering, v. 44, p. 59-75.

Nuttli, O. W., 1980, The excitation and attenuation of seismic crustal phases in Iran: BSSA, v. 70, p. 469-485.

Panagiotopoulos, D. G., and B. C. Papazachos, 1985, Travel times of Pn-waves in the Aegean and surrounding area: Geophys. J. Int., v. 80, p. 165-176.

Rogers, A. J., J. F. Ni, and T. M. Hearn, 1995, Pn, Sn, and Lg progagation in the Middle East.

Seber, D., M. Barazangi, B. A. Tadili, M. Ramdani, A. Ibenbrahim, D. B. Sari, and S. O. E. Alami, 1993, Sn to Sg conversion and focusing along the Atlantic margin, Morocco: implications for earthquake hazard evaluation: Geophys. Res. Letters, v. 20, p. 15031506.

Seber, D., and B. J. Mitchell, 1992, Attenuation of surface waves across the Arabian peninsula: Tectonophysics, v. 204, p. 137-150.

Snyder, D. B., and M. Barazangi, 1986, Deep crustal structure and flexure of the Arabian plate beneath the Zagros collisional mountain belt as inferred from gravity observations: Tectonics, v. 5, p. 361-373.

Soller, D. R., R. D. Ray, and R. D. Brown, 1982, A new global crustal thickness map: Tectonics, v. 1, p. 125-149.

van Eck, T., 1988, Attenuation of Coda in the Dead Sea Region: BSSA, v. 78, p. 770779 .

Xie, J., and B. J. Mitchell, 1990, A back-projection method for imaging large-scale lateral variations of $\mathrm{Lg}$ coda $\mathrm{Q}$ with application to continental Africa: Geophys. J. Int., v. 100, p. 161-181. 


\section{Generalized Tectonic Map of the Middle East and North Africa}

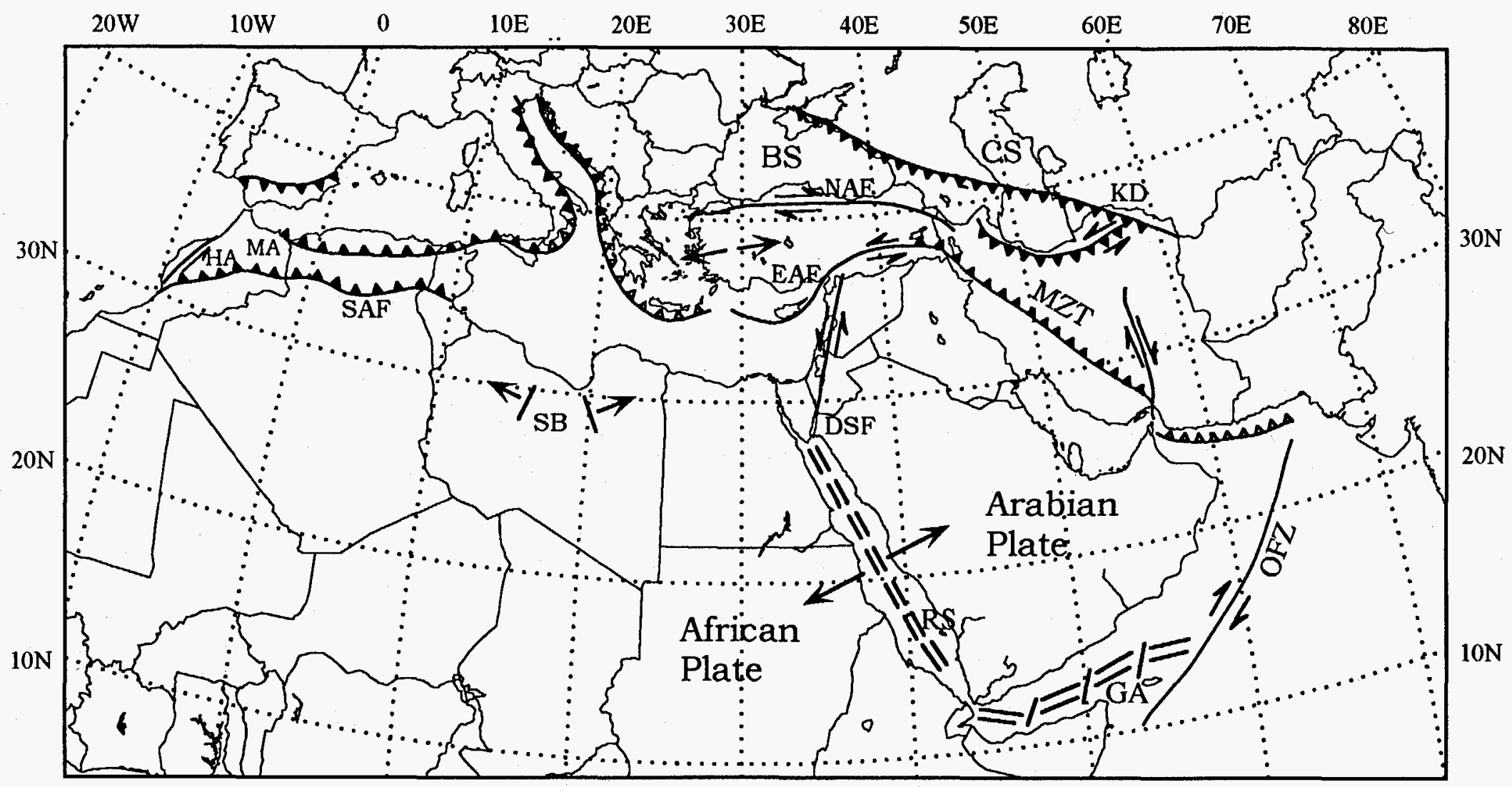

Figure 1. Generalized tectonic map of the Middle East and North Africa. BS - Black Sea; CS - Caspian Sea; DSF - Dead Sea Fault; EAF - East Anatolian Fault; GA - Gulf of Aden; HA - High Atlas; KD - Kopet-Dagh; MA - Middle Atlas; MZT - Main Zagros Thrust; NAF - North Anatolian Fault; OFZ - Owen Fault Zone; RS - Red Sea; SAF - South Atlas Fault ; SB - Sirt Basin

Solid triangles designate upper plate of thrust fault zones; open triangles designate upper plate of subduction zone; parallel lines designate ocean spreading center 


\section{Pn velocities in the Eastern Mediterranean}

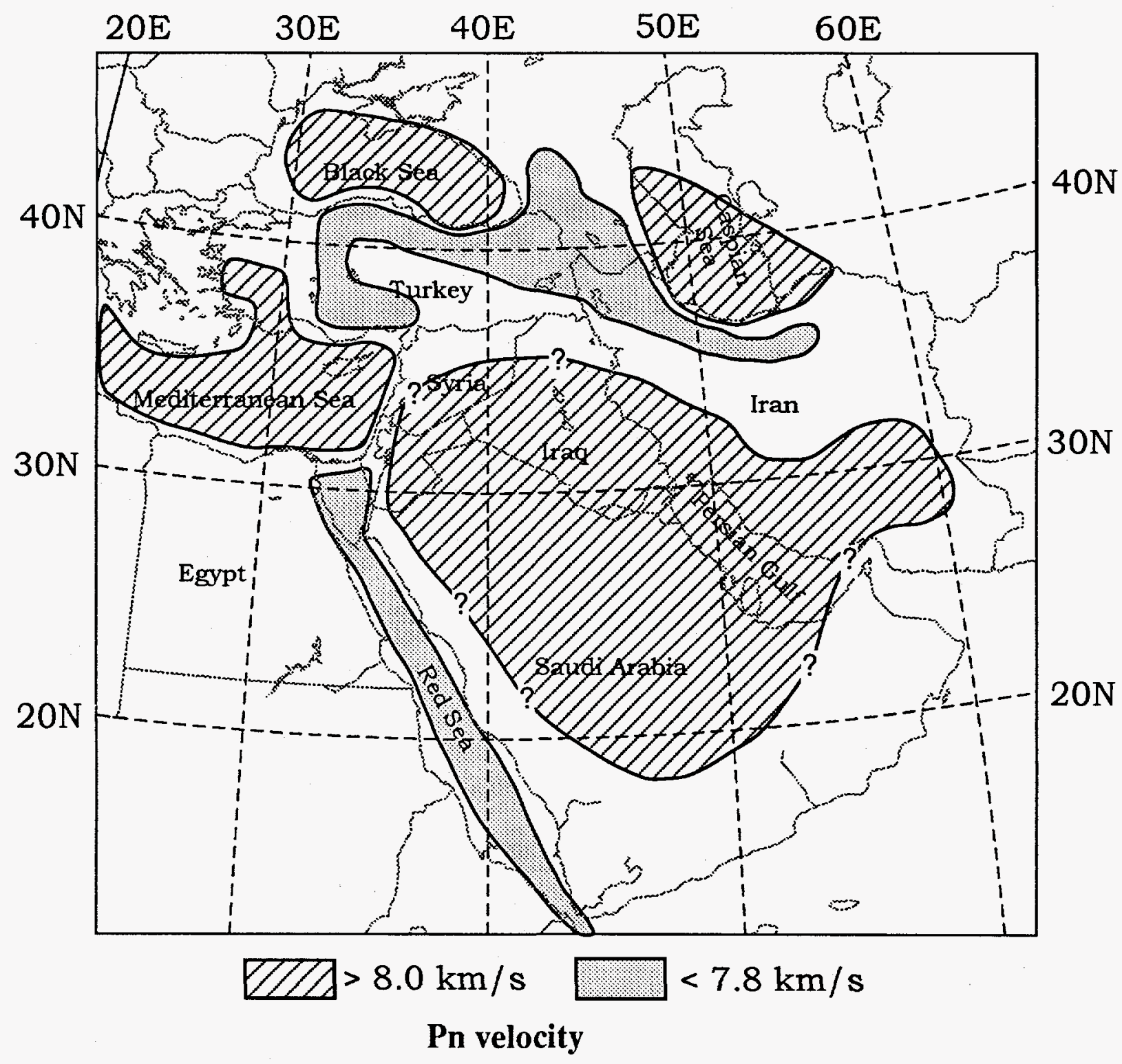

Figure 2. Map of Pn velocities in the Eastern Mediterranean region. 
Depth to Moho/Crustal Thickness (km)

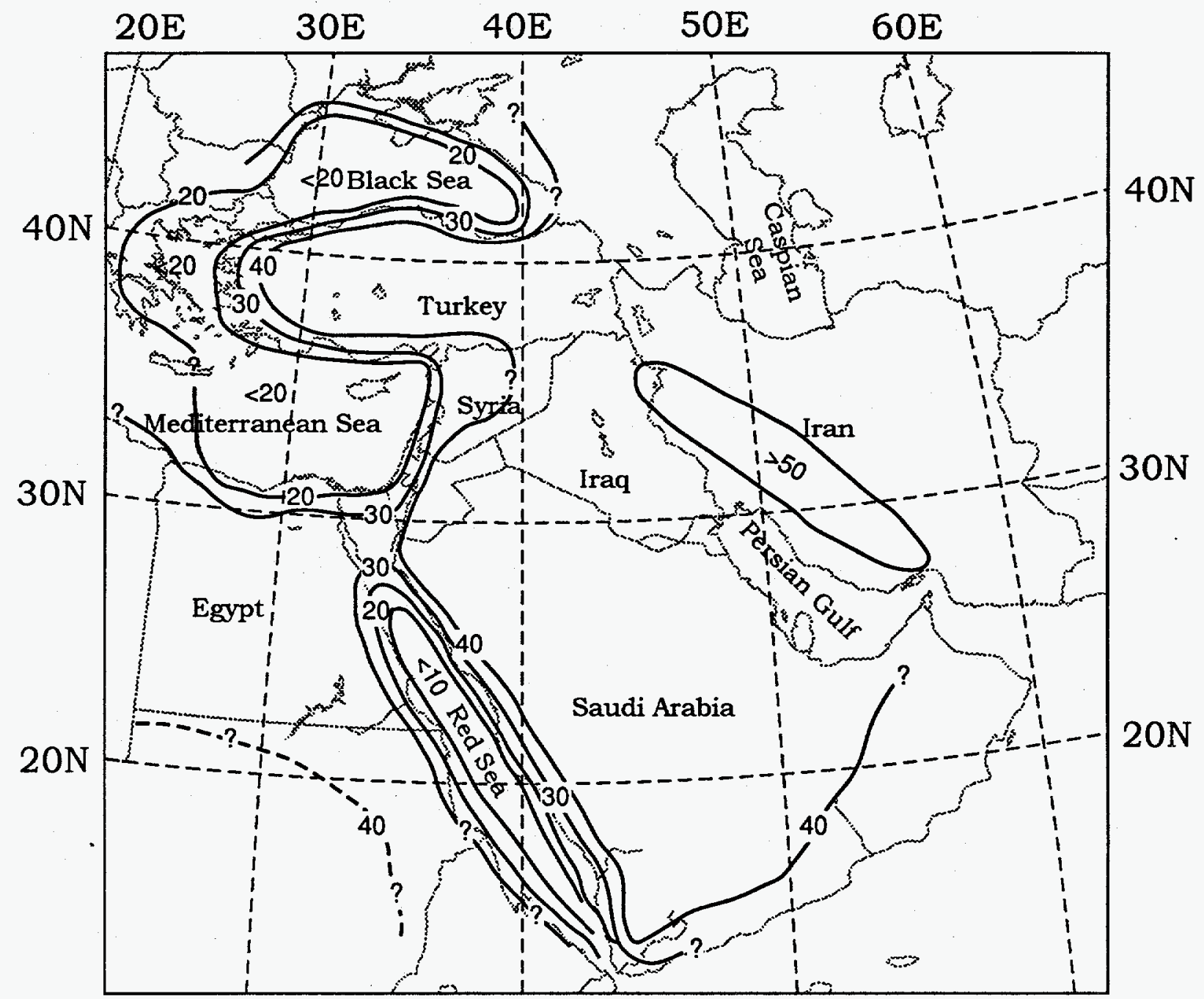

Figure 3. Map of the depth to Moho, or crustal thickness, in the eastern Mediterranean area. See text for references. 


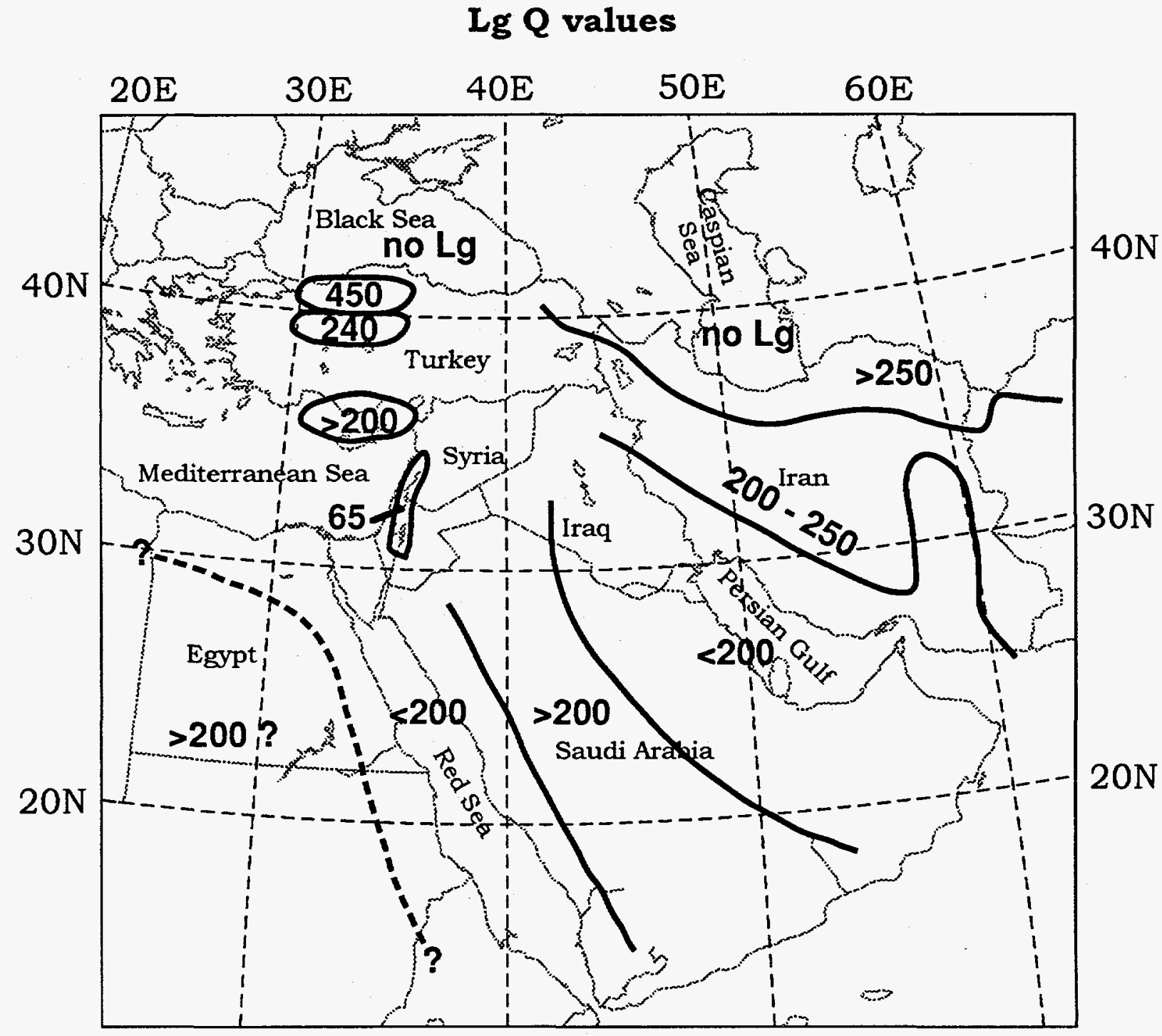

Figure 4. Values of $\mathrm{Lg} \mathrm{Q}$ in the eastern Mediterranean region. Most values are for $\mathrm{Lg} \mathrm{Q}$ at $1 \mathrm{~Hz}$. Values from southern Turkey are from studies of Qs; values for northern Turkey and the Dead Sea are from regional studies of coda $\mathrm{Q}$. See text for discussion and references. 
$\mathrm{Lg}$ (outline) and $\mathrm{Sn}$ (bold) velocities (km/s)

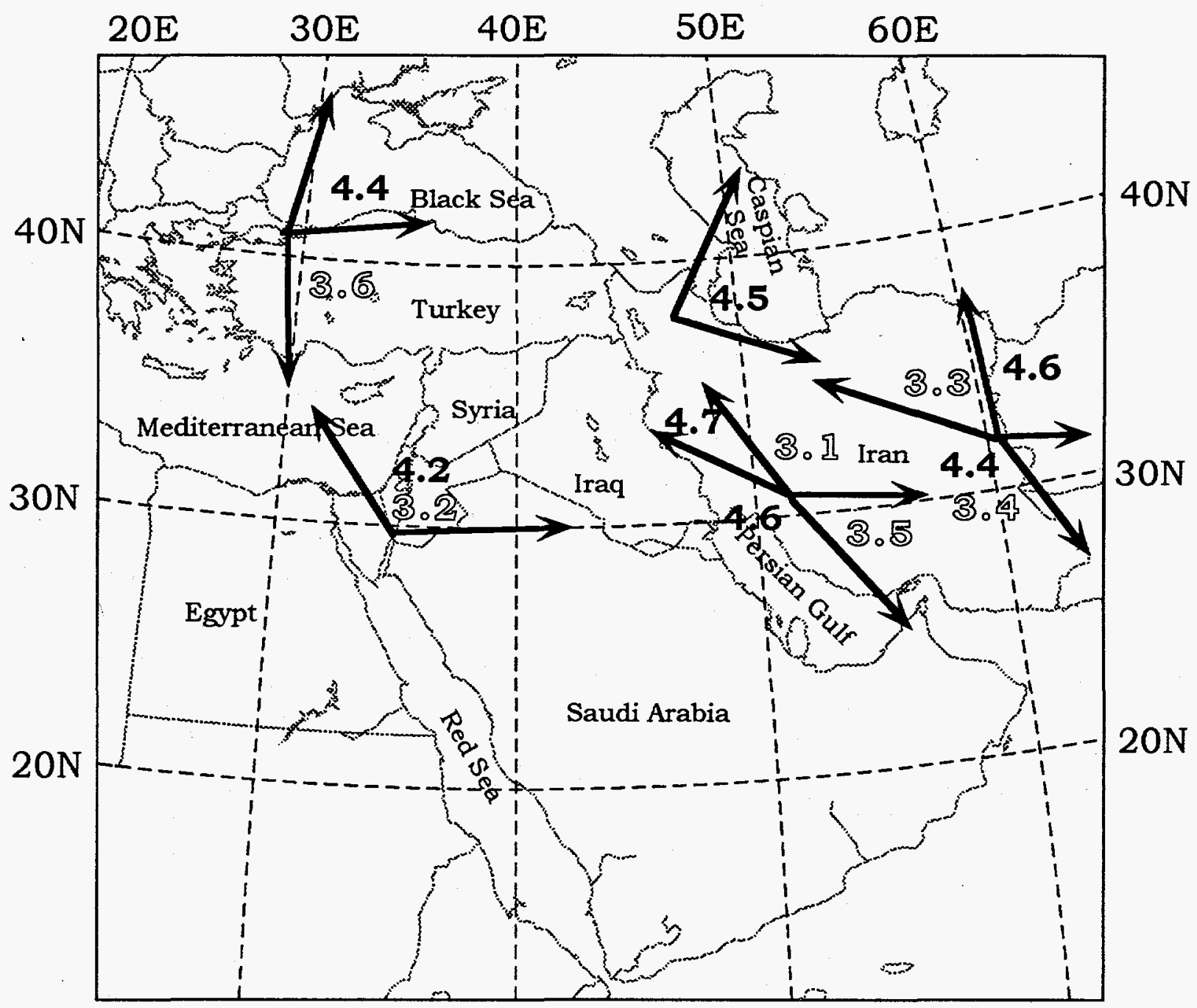

Figure 5. Map of $\mathrm{Lg}$ (outline style) and Sn (bold) velocities $(\mathrm{km} / \mathrm{s})$ in the eastern Mediterranean region. Data after Kadinsky-Cade et al. (1981). Arrows bracket direction of arrival of signals used to determine velocities (each velocity number is bound by two arrows showing the azmuthal limits of signal arrivals used in the determination). 


\section{Sn propagation characteristics}

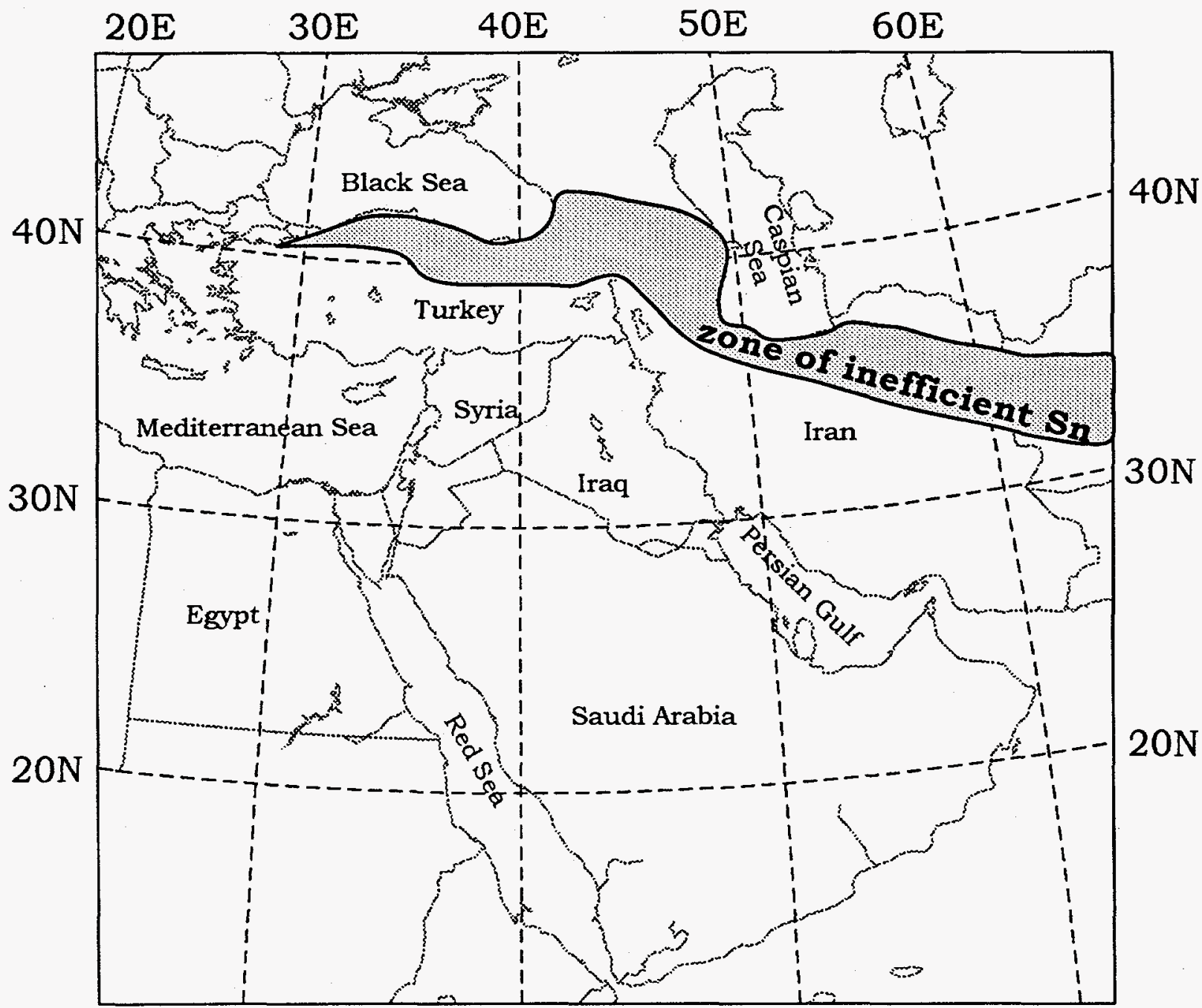

Figure 6. Map showing location of the zone of inefficient $\mathrm{Sn}$ phase propagation in the eastern Mediterranean. Low Pn velocity is associated with high $\mathrm{Sn}$ attenuation (Hearn and Ni, 1994; Rogers et al., 1995) and efficient Lg propagation (Jih and Lynnes, 1994). Refer also to Fig. 2. 
Morocco and offshore Atlantic Ocean

Pn (outline) and $\mathrm{Sn}$ (bold) velocities $(\mathrm{km} / \mathrm{s})$

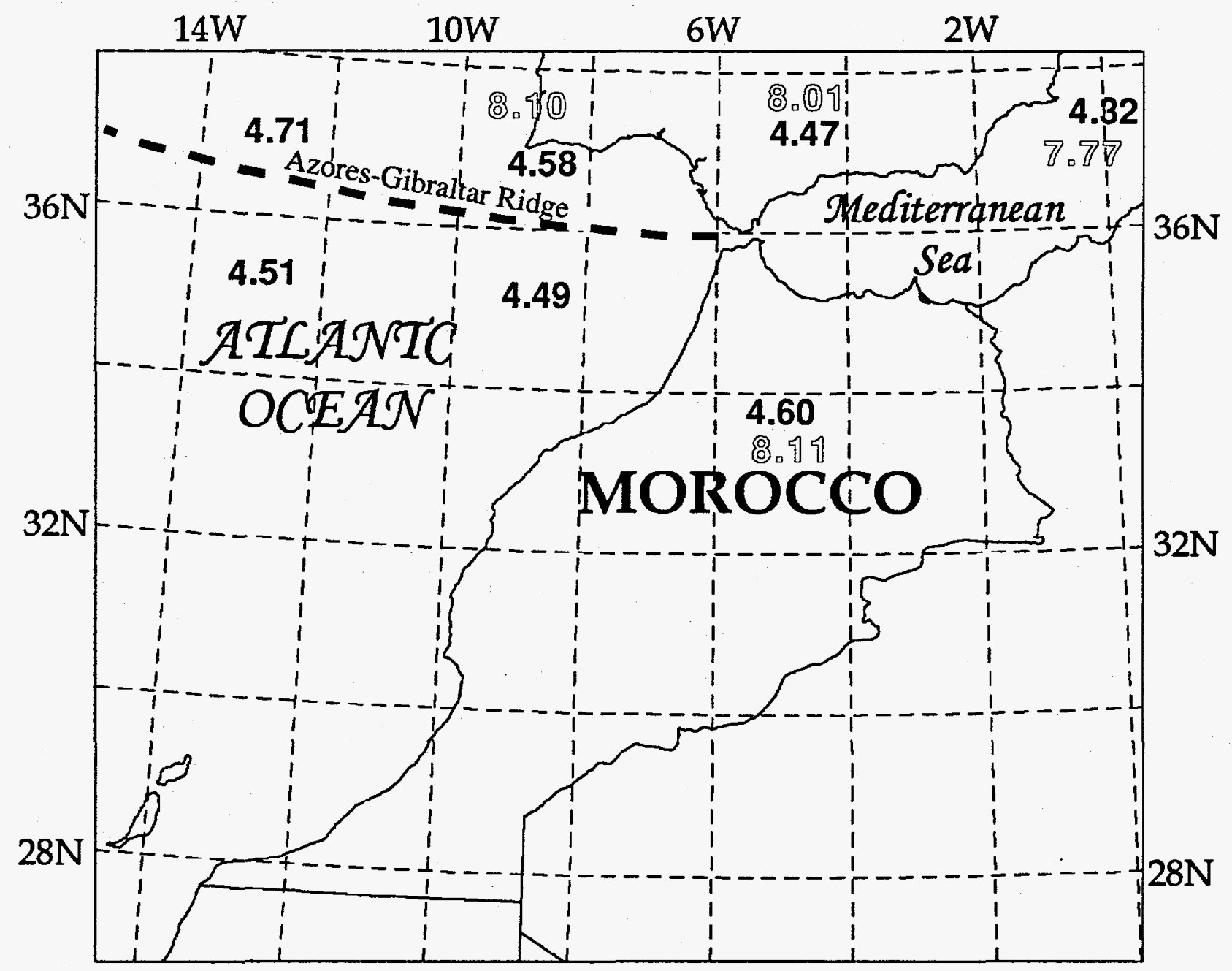

Figure 7. Pn (outline style) and $\mathrm{Sn}$ (bold) velocities $(\mathrm{km} / \mathrm{s})$ in the western Mediterranean region and offshore Atlantic Ocean. Determinations are from teleseismic, $50 \mathrm{~s}$ period data by Marillier and Mueller (1982). 